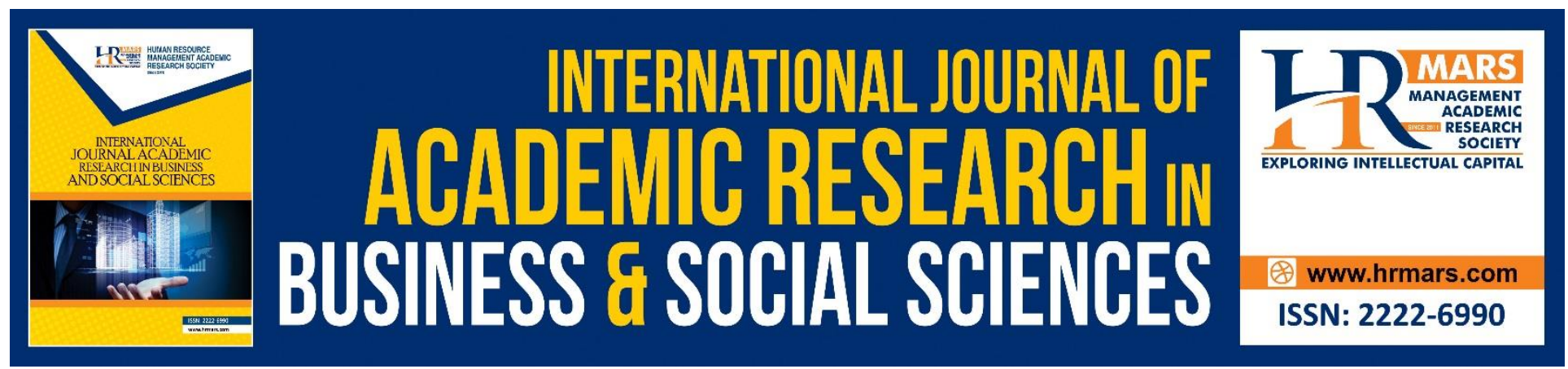

\title{
Does External Debt Cause Economic Growth? An Experience from ECOWAS Member Countries
}

Hammed Oluwaseyi Musibau, Suraya Mahmood, Suraya Ismail, Zelhuda Shamsuddin, Norfadzilah Rashid

To Link this Article: http://dx.doi.org/10.6007/IJARBSS/v8-i11/5167 DOI: $10.6007 /$ IJARBSS/v8-i11/5167

Received: 06 Nov 2018, Revised: 28 Nov 2018, Accepted: 02 Dec 2018

Published Online: 04 Dec 2018

In-Text Citation: (Musibau, Mahmood, Ismail, Shamsuddin, \& Rashid, 2018)

To Cite this Article: Musibau, H. O., Mahmood, S., Ismail, S., Shamsuddin, Z., \& Rashid, N. (2018). Does External Debt Cause Economic Growth? An Experience from ECOWAS Member Countries. International Journal of Academic Research in Business and Social Sciences, 8(11), 1256-1264.

Copyright: (C) 2018 The Author(s)

Published by Human Resource Management Academic Research Society (www.hrmars.com)

This article is published under the Creative Commons Attribution (CC BY 4.0) license. Anyone may reproduce, distribute, translate and create derivative works of this article (for both commercial and non-commercial purposes), subject to full attribution to the original publication and authors. The full terms of this license may be seen

at: http://creativecommons.org/licences/by/4.0/legalcode

Vol. 8, No. 11, 2018, Pg. 1256 - 1264

http://hrmars.com/index.php/pages/detail/IJARBSS

JOURNAL HOMEPAGE

Full Terms \& Conditions of access and use can be found at http://hrmars.com/index.php/pages/detail/publication-ethics 


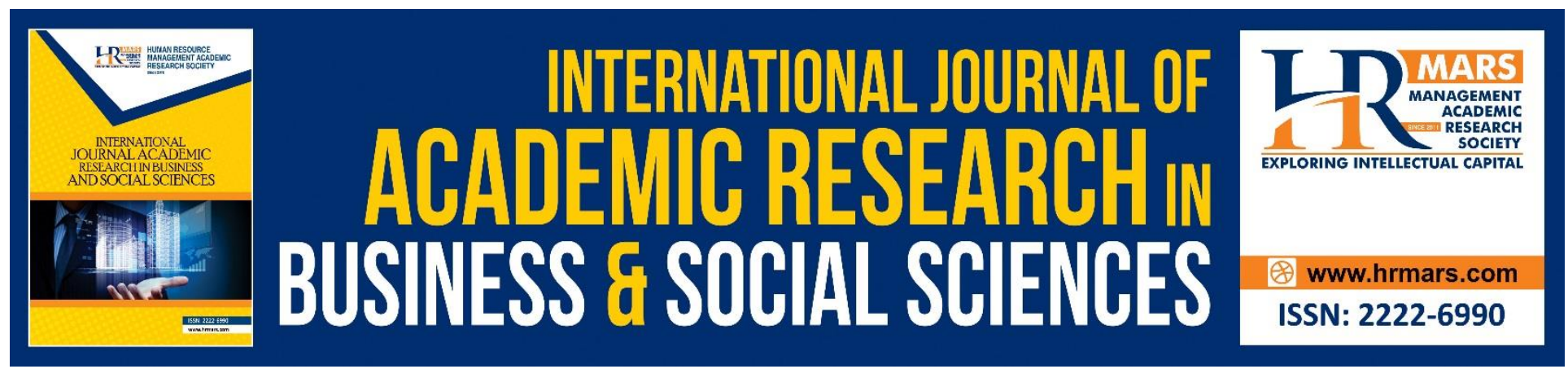

\title{
Does External Debt Cause Economic Growth? An Experience from ECOWAS Member Countries
}

\author{
Hammed Oluwaseyi Musibau, Suraya Mahmood, Suraya Ismail, \\ Zelhuda Shamsuddin, Norfadzilah Rashid \\ ${ }^{1}$ Faculty of Economics and Management Sciences, Universiti Sultan Zainal Abidin (UniSZa) | \\ Kuala Terengganu| Malaysia \\ Email: zelhudasham@unisza.edu.my
}

\begin{abstract}
West Africa countries had been ranked among the poorest sub-regions in the world due to inadequate capital to bridge the gap between savings and investments. The scholars suggested foreign capital flows especially external debt will solve this chronic problem. This study employed panel data from 1980 to 2015 to investigate causal effect between external debt and economic growth among ECOWAS member countries using Debt Overhang Theory. The result shows the existence of long and short run causality between external debt and economic growth economic integrated member countries. We concluded the availability of this foreign capital flows (External debt) will stimulate investments if it is judiciously used productively. A main challenge to the policy makers is ensuring efficiency in delivery of services and increased productivity of public investments and eradication of corruption. In addition, creating enable environment and political will to spur investor confidence for both local and foreign investments.
\end{abstract}

Keywords: Causality, External Debt, Corruption, Growth, ECOWAS.

\section{Introduction}

It is presumed that debt has been a constraint to growth and development in Africa. Debt burden "has become one of the most important factors constraining recovery and development in the continent. Ayadi and Ayadi (2008) concludes that debt crowds out investment in Africa. He suggests that, reduction its burdens could contribute substantially to economic growth in Sub Sahara Africa. Even though, government needs resources for public expenditure and it expected that borrowing increases resource availability. Most of external debt in Africa was obtained for political reasons hiding underdevelopment purpose. Therefore, unless used productively, borrowings could soon begin to strain government finances, as more and more resources have to be diverted for debt service, which would leave less money for routine and development expenditure. A misuse of resources may easily lead to a buildup of debt to unsustainable levels which has been a major impediment to growth in emerging economies. 
External debt problem is one of the main challenges faced by the developing economies like most Sub Sahara African countries. Pattillo et al. (2002) hinted that, conditions of external debt in term of the repayment or "debt service" creates problems for many countries especially Africa. Nigeria the largest economy among ECOWAS was given debt forgiveness from Paris club after paying 3 times of the actual debt. West Africa countries had failed to take into consideration the issue of debt servicing. As a result, large debt service payments had a lot of constraint economic performance of most West African countries. According to World Bank Report 2011 concluded developing countries like West African countries suffered a foreign debt burden and debt servicing rather than developed countries.

\subsection{External Debt and Economic Growth in Africa.}

Generally, the developing countries had been facing increase in external debt over decades coupled with fact that most of these countries were running deficit budget in the name of developing infrastructure but rather used for deadweight projects and servicing political offices. According to Raffinot and Venet (2017) hinted that, the external debt stock of low- and middle income countries declined for the first time in more than two decades. External debt stocks fell 6 percent, to $\$ 6.7$ trillion. The main contributors to this decline were net debt outflows in conjunction with year-on-year exchange adjustments between the currencies in which external debt is denominated and the U.S. dollar (the numeraire). Outflows were driven by an 18 percent contraction. Looking beyond debt, net financial flows (debt and equity) dropped to \$379 billion, one third the 2014 level (\$1,159 billion). This was equivalent to 1.5 percent of low- and middle-income countries' combined GNI, down from an average of 4.9 percent in 2013-14. Equity-based foreign direct investment (FDI) proved resilient and offset the precipitous fall in debt and portfolio equity flows. FDI held steady at $\$ 543$ billion in 2015 , marginally higher than the previous year. Portfolio equity flows were positive in 2015 for the fourth successive year, but fell sharply to $\$ 21$ billion (\$81 billion in 2014).

Net debt inflows drop to \$184 billion, in 2015 against \$542 of 2014 in developing economies (IDS,2017) However in Africa, Net financial flows (debt and equity) rose 18 percent in 2015 , to $\$ 28$ billion so the boarding of increases in the region. Inflows to Nigeria and Congo is not encouraging due to fall in global oil prices with affect developmental projects of these countries (IDS 2017).

\subsection{External Debt and economic growth in ECOWAS countries}

The total external debt stock of low- and middle-income countries fell 6 percent in 2015, to $\$ 6.7$ trillion. It was the first year in more than two decades where debt stocks did not rise a marked contrast to the 10 percent increase in 2013-14. This decline was driven by a combination of net debt outflows of $\$ 184$ billion, debt forgiveness, and the downward effect of the U.S. dollar appreciation on year-on-year exchange adjustments (more than half the debt of low- and middleincome countries is denominated in currencies other than U.S. dollars).

For Sub-Saharan Africa (excluding South Africa), FDI in 2015 was little changed from 2014, but with some important shifts across recipient countries. Angola, far and away the largest recipient, attracting $\$ 9.5$ billion; local affiliates counteracted the economic downturn by borrowing from parent companies to strengthen their balance sheets. Inflows to Nigeria were dragged down by 
lower oil prices and delays in some major exploration projects, and those to the Republic of Congo fell sharply.

However, the impact was largely concentrated in market-based borrowers like Botswana and Mauritius, and in oil exporters, notably Angola and the Republic of Congo. Flows to Nigeria the largest economy among ECOWAS countries turned negative but held up better than expected, given the fall in global oil prices and the concomitant downturn in the country's macroeconomic prospects(Chuhan-Pole, 2016).

Figure 1: External Debt stock in the World, 2010-15 US\$ (billion)

Sources: World Bank Debtor Reporting System, International Monetary Fund, and Bank for International Settlement 2017.

The aggregate figure masks some wide divergence in the pace of debt accumulation at the individual level, with some countries in Sub-Saharan Africa recording the fastest rising external debt levels of any low- and middle-income countries. Between end 2013 and 2015, the external debt stock Ethiopia, Kenya, Liberia, Nigeria, and Zambia rose by over 35 per cent and that of another 16 countries in the region by more than 10 percent. In figure 1 shows that Sub-Sahara is the lowest recipient of foreign debt among other continents. In several countries, the rapid rise in outstanding external debt is attributable to large bond issuance in international capital markets. The impact of a sharp increase in external obligations at a time when global economic outcomes have heightened vulnerability to exogenous shocks is evident from the change in the debt-to export ratio of countries in the region. This ratio rose to 116 percent at end 2015 from 87 percent at end 2014. As expected, some of the most severely affected countries were those dependent on oil or mineral exports like Nigeria and Zambia.

The issue of external debt is one of the banes affecting African economies especially ECOWAS nations. The global debt especially of ECOWAS countries had centre stage in the global discussion for more than 3 decades. In deed external debt has imposed huge cost on the debtor country especially low income countries like ECOWAS countries in term of low economic growth and public investments crowd out. ECOWAS countries have been experiencing huge of external debt coupled with servicing cost which is affecting the value of the currencies therefore discouraging foreign investors in the region. The effect of huge amount of external debt has made it difficult to achieve the presume growth in the region which is retarded by excessive loans by pre-empting limited foreign exchange for debt servicing. The high external debt-servicing in ECOWAS countries has depleted savings and foreign exchange resource that have been used to supplement domestic investments and provision of infrastructures to induce foreign investment. However, ECOWAS countries' excessive debt stock has not encouraged the flows of foreign capital like foreign domestic investment due to fear of macroeconomic distortions. Instead attracting capital inflows from abroad, domestic capital are swamping abroad in form of capital flight for security. Thus revenues from investments were deficient to meet maturing obligations and affecting economic growth. So, African economies, especially ECOWAS countries have not done well, due to bigger outflow of funds to service debt among ECOWAS countries. 
INTERNATIONAL JOURNAL OF ACADEMIC RESEARCH IN BUSINESS AND SOCIAL SCIENCES Vol. 8, No. 11, Nov, 2018, E-ISSN: 2222-6990 @ 2018 HRMARS

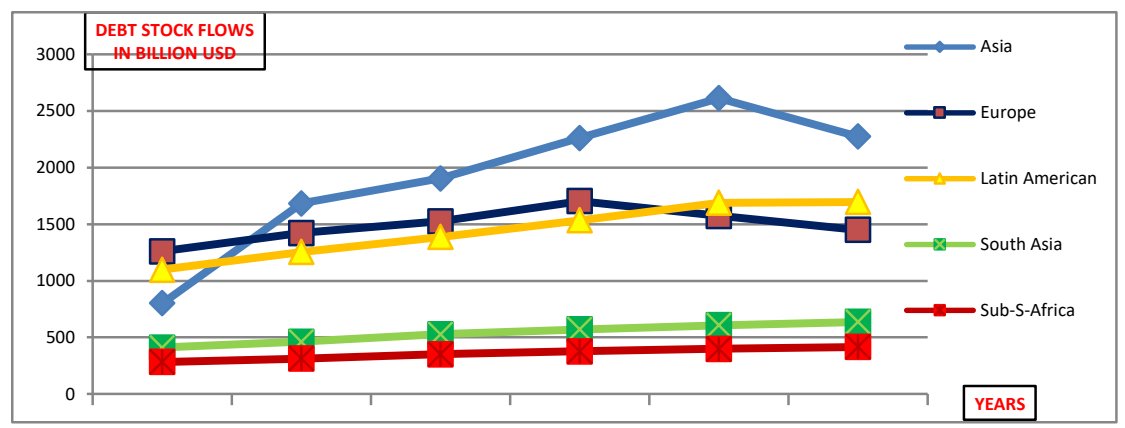

\section{LITERATURE REVIEW}

The studies on the impact of external debt to economic growth had created a lot argument among the scholars on whether external debt reduce economic growth or increase growth. Among the theoretical literature tends to point to a negative link between the public debt-to-GDP ratio and the steady-state growth rate of GDP per capita can be seen in Cecchetti et al (2011) investigates the impact of external debt on economic growth among 18 OECD countries over the period 1980-2006. They conclude that a debt by GDP 10 per cent. Contrary to the finding of Egert's (2012) hints on negative correlation between debt and growth decreases. Similarly, Afonso and Jalles (2013) show that, in a sample of OECD countries, the average growth rates over the period 1970-2008 of countries. He found that debt crowd out growth by 30 per cent in OECD countries. However, Greiner (2011) hinted that there are no rigidities and elastic labor sup-ply, public debt has a negative effect on labor supply, investment, and economic growth. Other economists argue that high levels of public debt have a negative effect on economic growth and that fiscal consolidation is necessary to anchor expectations and restore confidence (Panizza and Presbitero 2013). Public debt could have a larger negative effect on economic outcomes if it affects the productivity of public expenditures ( Teles and Cesar Mussolin, 2014), increases uncertainty or creates expectations of future financial repression (Akitoby et al 2014) In contrast, are cent study by Reinhart and Rogoff(2010), which analyses (through simple correlation statistics) the developments of public (gross central government) debt and the long-term real GDP growth rate in a sample of 20 developed countries over a period spanning about two centuries (1790-2009), finds that: (i) the relationship between government debt and long-term growth is weak for debt/GDP ratio s below a threshold of $90 \%$ of GDP and (ii) above this threshold, the median growth rate falls by one percent point and the average by considerably more (about 4 percent. Checherita-Westphal and Rother (2012) focus on 12 euro-area countries over the period 1970-2008 using Instrument variable and found that growth reaches a maximum when the debt-to-GDP ratio is about 90-100 percent.

Theoretical argued that, high public debt has a negative effect on GDP growth are in line with a growing empirical literature which shows that there is a negative non - linear correlation between public debt and economic growth (Reinhart and Rogoff, 2009, 2010; Reinhart et al., 2012; Kumar and Woo, 2010; Cecchetti et al. 2011; Checherita et al. 2012; Furceri and Zdzienicka, 2012). While those in support of positive association between external debt and growth are (Abbas, 2007; Christensen 2010; Maana et al. 2008; Aminu and Anono 2012; Godfrey \& Cyrus, 2013; DeLong and Summers 2012; Hallett, and Rother, 2012). Moreover, many previous studies on the relationship between external debt and economic growth show that some researchers found positive relation some said it is negative and some no significant relationship between 
external debt and economic growth for different economic condition. We discovered inconsistencies in findings among Thus, the objective of this paper was to examine the impact of external debt on the economic growth performance among ECOWAS member countries for the period of 1970-2015.

\subsection{Methodology}

\subsection{Theoretical Framework}

Debt Overhang Theories

The theory argues that large levels of accumulated debt cause to lower growth. There is some likelihood that, in the future, debt will be larger than the country's repayment ability, expected debt-service costs will discourage further domestic and foreign investment and thus harm growth. However, IMF (2002) hints reasonable levels of external debt that help finance productive investment is expected to cause economic growth, but limit need to be set as further indebtedness may diminish growth.

This study investigates the impact of external debt as one of the major source of foreign capital inflows to ECOWAS member countries using panel data from 1980 to 2015.

\subsection{Mode Specification}

To explore whether public debt has a causal effect on economic growth, we build on an influential paper of Cecchetti et al. (2011). We stay as close as possible to their work by using the same data, sample (with the exceptions mentioned in the previous section), and empirical approach. Formally, we use five-year overlapping growth spells to estimate the following regression

InRGDPit $=\beta 0+\beta 1($ InEXTDEBT $) i t+\beta 2($ INTEXTDEBT $) i t+\beta 3($ DSAVINGS $) i t+$ $\beta 4(D I N V T) i t+\beta 5(C O R R U P) i t+\beta 6($ InINT $) i t+\mu i t$

Where RGDP is Real GDP per capita, EXTDEBT represents external debt and INTEXTDEBT is Interest on external debt, DSAVING is domestic saving, DINVT is domestic Investment, CORRUP is Index of corruption and INT is real Interest Rate. Also, Bi-B6, = are coefficients, Bo is constant and $\mu$ is stochastic error term. The error term $\mu$ consists of country- and time-specific effects as follows: $\mu \mathrm{it}=v i+\gamma \mathrm{t}+\varepsilon i \mathrm{t}$

\section{Finding and Discusions}

\subsection{Panel Unit Root}

The results of the panel unit root tests conducted for the seven variables (GDP, External Debt, Interest rate on External Debt, Domestic Investment, Domestic Savings, Corruption Index, Interest rate). According to Table 4.1 below, all the variables were non-stationary at level. Consequently, the panel unit root test of Levin, Lin and Chin and Im, Pesaran and Shin were again test for all the variables at first differenced. The results indicate that all the variables are stationary at I (1) or in other words all the variables are integrated of order of one. 
INTERNATIONAL JOURNAL OF ACADEMIC RESEARCH IN BUSINESS AND SOCIAL SCIENCES

Vol. 8, No. 11, Nov, 2018, E-ISSN: 2222-6990 @ 2018 HRMARS

Table 4.1

Panel Unit Root Test

\begin{tabular}{lllll}
\hline Variable & $\begin{array}{c}\text { Level } \\
\text { LLC }\end{array}$ & IPS & LLC & IPS \\
\hline GDP & -0.3846 & -0.8867 & $-5.4314 * * *$ & $-7.87295^{* * *}$ \\
EXTDEBT & 2.37092 & 1.6172 & $-14.097 * * *$ & $-14.4666 * * *$ \\
INTEXTDEBT & 2.0490 & -0.5863 & $-6.3319 * * *$ & $-2.2305 * * *$ \\
DINVEST & 4.9969 & 6.6525 & $-5.8658 * * *$ & $-7.57326 * * *$ \\
DSAVINGS & -0.694 & -0.9502 & $-6.5325 * * *$ & $-6.5246 * * *$ \\
CORRUPT & 1.8235 & 3.0515 & $-10.625 * * *$ & $-11.4168 * * *$ \\
INTRATE & 3.8849 & 2.5232 & $-12.808 * * *$ & $-14.7189 * * *$ \\
\hline
\end{tabular}

Notes, $* * *, * *$ and $*$ indicate the rejection of the null hypothesis at $1 \%, 5 \%$ and $10 \%$ significant level respectively.

Table 4.2 Johansen cointegration test's Result (Pedroni Result).

\begin{tabular}{|c|c|c|c|}
\hline S/No & Test & Statistic & Prob \\
\hline 1 & v-Statistic & 3.069880 & 0.0011 \\
\hline \multirow[t]{2}{*}{2} & PanelrhoStatistic & - & \\
\hline & & 1.572801 & 0.0579 \\
\hline \multirow[t]{2}{*}{3} & PanelPPStatistic & - & \\
\hline & & 20.51002 & 0.0000 \\
\hline \multirow[t]{2}{*}{4} & PanelADFStatistic & - & \\
\hline & & 13.41596 & 0.0000 \\
\hline 5 & Group rhoStatistic & 1.582720 & 0.9433 \\
\hline \multirow[t]{2}{*}{6} & Group PPStatistic & - & \\
\hline & & 6.622363 & 0.0000 \\
\hline \multirow[t]{3}{*}{7} & GroupADFStatistic & - & \\
\hline & & 9.067422 & 0.0000 \\
\hline & Coeff $\quad$ Std-Error & t-Stats & Prob \\
\hline$E C T$ & -0.55790 .3131 & -1.7816 & 0.0758 \\
\hline $\operatorname{Adj} R^{2}$ & 0.965 & & \\
\hline $\begin{array}{l}\text { F- } \\
\text { stat }\end{array}$ & 200.8458 & & \\
\hline \multicolumn{4}{|c|}{$\begin{array}{l}\text { Ho: no serial correlation, } \text { chi } 2=0.689 \text { Prob }>\text { chi } 2= \\
0.4065\end{array}$} \\
\hline
\end{tabular}

The result of from the Pedroni test, at $5 \%$ level of significant all the variables under the Panel vStatistic, the Panel ADF-Statistic, Panel rho-Statistic and Panel PP-Statistic null hypothesis shows a long run relationship meaning that null hypothesis was accepted at that $5 \%$ level. We have the validity to test for long run causality via VECM. The ECT coefficient is -0.5579 and statistically significant. We conclude that External debt and its components cause growth in the long run. The speed of adjustment towards long run equilibrium is 56 per cent. The Granger causality results at lag 2 for short run causality (presented in table 4.3) also confirmed that external debt, interest 
payment on external debt, domestic investment and saving caused growth in the short run. Our findings support (Abbas, 2007; Butts 2009; Christensen 2010; Maana et al. 2008; Aminu and Anono 2012; Godfrey \& Cyrus, 2013). Butts (2009) short- and long- runs Granger causality from economic growth to short-term external debt is present in Caribbean and Latin American countries. With the evidence suggesting, in the majority of estimated cases, economic growth Granger caused short-term external debt, short-term policy decisions related to capacity absorption enhancement should be encouraged in Latin America and the Caribbean. He encouraged panel studies with inclusion of omitted variables that could influence economic growth. The novelty of our study as to do with inclusion of sensitive variables like payment for serving external debt and also the impact of corruption in the region of study which is very imperative when it comes to external debt management.

Table 4.3: Wald Test (Short Causality Test)

\begin{tabular}{|c|c|c|c|}
\hline Dependent & & GDP & Probability \\
\hline Variables & & Value & \\
\hline$\overline{\text { EXTDEBT }}$ & $\rightarrow$ & $\overline{5.62615}$ & 0.0002 \\
\hline INTEXTDEBT & $\Gamma \rightarrow$ & 18.3599 & 0.0000 \\
\hline DINVEST & $\rightarrow$ & 80.8562 & 0.0000 \\
\hline DSAVING & $\rightarrow$ & 335.373 & 0.0000 \\
\hline CORRUP & $\rightarrow$ & -0.33374 & 0.8553 \\
\hline INTRATE & $\rightarrow$ & 0.07776 & 0.9891 \\
\hline
\end{tabular}

N.B: * Indicates significant at the $5 \%$ level.

Authors Computation 2017

Post examination in Table 4.2 shows that the model is fit and no presence of series correlation.

\section{Conclusion}

This study investigates the causality between external debt and economic performance among ECOWAS member countries via panel co-integration and Granger causality methods from 1980 to 2015. The empirical results provide strong evidence of the impact of the external debt on economic growth among the economic integration ECOWAS and conclude that efficient investment on foreign capital flow (External debt) to build infrastructure, energy consumption in a corrupt free environment will cause growth. The result is in support of findings from (Aminu and Anono 2012; Godfrey \& Cyrus, 2013; and Rother 2012) suggest that there is positive relationship between external debt and economic growth but in contrary to the opinions of (Panizza \& Presbitero, 2014; Reinhart and Rogoff, 2012; Kumar and Woo, 2010; Cecchetti, Mohanty and Zampolli, 2011) has found a negative correlation between debt and growth. Panizza and Presbitero 2014 found that there is no evidence that public debt has a causal effect on economic growth. We suggest that any policy targeting foreign capital in term of external debt make sure it is invested judiciously not on deadweight expensive like to conduct election or celebrity independence as it common among West Africa countries. 
INTERNATIONAL JOURNAL OF ACADEMIC RESEARCH IN BUSINESS AND SOCIAL SCIENCES Vol. 8, No. 11, Nov, 2018, E-ISSN: 2222-6990 C 2018 HRMARS

\section{References}

Afonso, A., \& Jalles, J. T. (2013). Growth and productivity: The role of government debt. International Review of Economics \& Finance, 25, 384-407.

Ayadi, F. S., \& Ayadi, F. O. (2008). The impact of external debt on economic growth: A comparative study of Nigeria and South Africa. Journal of Sustainable Development in Africa, 10(3), 234-264.

Butts, H. C. (2009). Short term external debt and economic growth-Granger causality:

evidence from Latin America and the Caribbean. The Review of Black political economy, 36(2), 93-111.

Chuhan-Pole, P. (2016). Africa's Pulse Spring 2016. World Bank Publications.

Checherita-Westphal, C., \& Rother, P. (2012). The impact of high government debt on economic growth and its channels: An empirical investigation for the euro area. European Economic Review, 56(7), 1392-1405.

Furceri, D., \& Zdzienicka, A. (2012). How costly are debt crises?. Journal of International Money and Finance, 31(4), 726-742.

Greiner, A. (2011). Economic growth, public debt and welfare: Comparing three budgetary rules. German Economic Review, 12(2), 205-222.

Pattillo, C. A., Poirson, H., \& Ricci, L. A. (2002). External debt and growth(No. 2002-2069). International Monetary Fund.

Panizza, U., \& Presbitero, A. F. (2013). Public debt and economic growth in advanced economies: A survey. Swiss Journal of Economics and Statistics, 149(2), 175-204.

Putunoi, G. K., \& Mutuku, C. M. (2012). Domestic debt and economic growth nexus in Kenya. Current Research Journal of Economic Theory, 5(1), 1-10.

Reinhart, C. M., Reinhart, V. R., \& Rogoff, K. S. (2012). Public debt overhangs: advancedeconomy episodes since 1800. The Journal of Economic Perspectives, 26(3), 69-86.

Teles, V. K., \& Mussolini, C. C. (2014). Public debt and the limits of fiscal policy to increase economic growth. European Economic Review, 66, 1-15. 